\title{
Effect of High Altitude Hypoxia on the Postnatal Development of Rat Testis: Histological and Histometric Study
}

\author{
Efecto de la Hipoxia a Gran Altitud en el Desarrollo Postnatal \\ en Testículos de Rata: Estudio Histológico e Histométrico
}

\author{
Heitham Mutwakil Mohammed" \& Tingari, M. D.**
}

MOHAMMED, H. M. \& TINGARI, M. D. Effect of high altitude hypoxia on the postnatal development of rat testis: Histological and histometric study. Int. J. Morphol., 34(2):610-615, 2016.

SUMMARY: The study was carried out at two different altitudes in the southern region of Saudi Arabia: Abha, 2,800 meters above sea level, the high altitude (HA) area and Jazan, 40 meters above sea level the low altitude (LA) area. Following exposure to high altitude, and up to the third week of postnatal development, some of the seminiferous tubules showed detachment from the basal lamina, spaces of different sizes within the epithelial layer with vacuoles in the center and Pyknotic nuclei were noted in the spermatogonia and primordial germ cells. Rounded spermatids were seen in the lumen only on day 35 of hypoxic group, no spermatozoa were recognized until day 45 of postnatal development. On day 45 hypoxic rat testes revealed various types of atrophy and degeneration in the seminiferous tubules and in the interstitial tissue, there was detachment of the basal laminae of the tubules and a profound decrease in cellularity. Significant decrease in epithelial height was noticed in these animals $(\mathrm{P}<0.05)$. Also, the diameter of the tubules showed slight decrease with concomitant increase in interstitial spaces in all hypoxic rats.

KEY WORDS: High altitude; Low altitude; Hypoxia.

\section{INTRODUCTION}

At high altitude, hypoxia is the critical stress factor influencing reproductive health. During the past decades, a number of studies have dealt with growth, development and reproduction under hypoxic conditions (Timiras et al., 1957). High altitude hypoxia delays onset of puberty in female rats (Nelson \& Srebnik 1970). In adult male rodent, hypoxia inhibits gonadotropins synthesis and release (Khmel nitskii \& Tararak, 1991).

Chronic hypoxia induces a decrease in plasma testesterone level without changing testesterone biosynthesis in vitro (Fahim et al., 1980). Moreover, chronic hypoxia arrests spermatogenesis in rats (Gosney, 1984) and monkeys (Saxena, 1995). However, studies on the effects of hypoxia on testis development are few. In previous publications, it was shown that the exposure of male rats to continuous chronic hypobaric hypoxia and intermittent chronic hypobaric hypoxia induced evident changes in testicular morphology, loss of germinal cells, arrest of spermatogenesis and metabolic stress in the mitochondria of round spermatids, consistent with oxygen consumption processes related to lipid peroxidation (Farias et al., 2005a). Furthermore, high altitude exposure has been shown to induce oxidative stress (Vats et al., 2008) that is accompanied by decreased levels of reduced glutathione and ascorbic acid and by an increase in antioxidant enzymes like glutathione reductase. Thus, a likely mechanism of hypobaric hypoxia-induced inhibition of spermatogenesis and sperm production can be related to an oxidative stress inmale reproductive organs (Farias et al., 2005a). Lipid peroxidation has been implicated in decreased organ weight, tissue damage, cell loss and cellular aging processes (Voss \& Siems, 2006). It has been established that in exposition times to $\mathrm{HH}$ above sixty days, there is morphological injury in the seminiferous tissue, associated with energetic and metabolic alterations in spermatogenic cells (Farias et al., 2005b).

\footnotetext{
* Department of Anatomy, College of Medicine, Jazan University, Jazan, Saudi Arabia.

** Department of Anatomy, Faculty of Veterinary Medicine, University of Khartoum, Khartoum, Sudan.
} 


\section{MATERIAL AND METHOD}

Experimental design. Sixty rats were used in the present study. The animals were divided into two groups; control group (24) rats and hypoxic group (36) rats. Rats of the control group will further subdivided into six subgroups of four each. Rats of the hypoxic group will subdivided into six groups of six each. Levels of testosterone in the plasma were measured on days 7, 14, 21, 28, 35 and 45. Histological and ultrastructural observations were carried out in accordance with the routine technique.

The animals were kept in separate cages under standard laboratory conditions and fed on dry straw, concentrated food and water ad libitum. Stages of development will be correlated with important events during postnatal development (PND) in the male rat i.e. PND 3-7 days (perinatal period), PND 14 days (eye opening as well as active myelation), PND 21 days (weaning), PND 28-35 days (prepubertal days), and PND 45 days (gonadal maturation achieved).

\section{Methods}

Tissue collection: All animals in all groups were sacrificed by overdose of anaesthesia and both testes were removed and transferred into petri dishes. The adipose tissues, connective tissues and blood vessels were dissected out and then weighed. Later, relative testis weight was then calculated per final body weight.

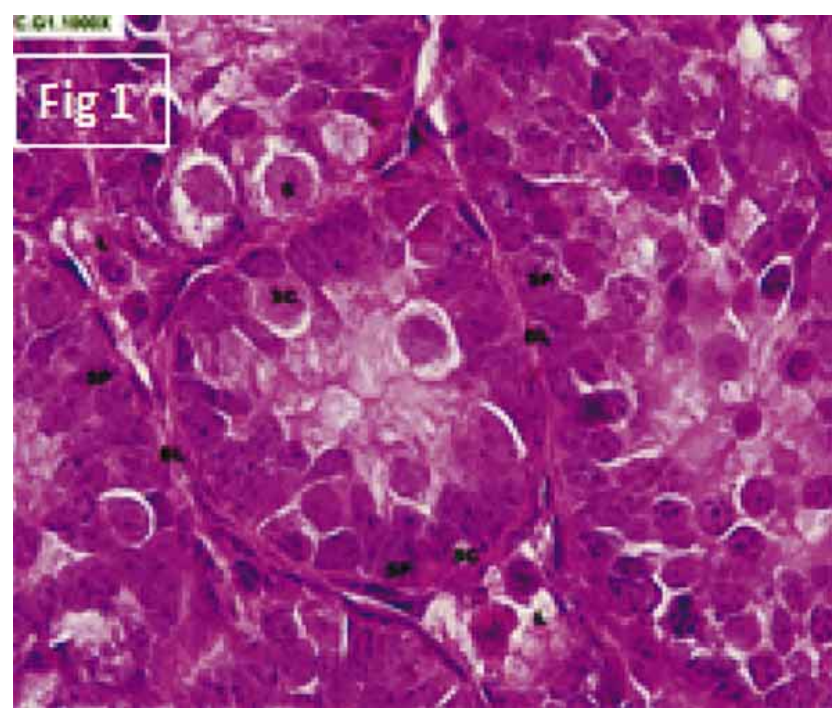

Fig. 1. A high power of seminiferous tubules of the testis of control rats (postnatal day 7) showing basal lamina (BL), spermatogonia (SP), sustentocytes (SC) resting on the basal lamina and interstititial endocrine cells (Leydig cell) (L) in the interstitial tissue (H\&E, $\mathrm{X} 1000)$.
Histology and histometry: Small pieces from one testis were fixed in $10 \%$ formalin, processed, for paraffin sections, stained with haematoxylin \& eosin, and then used for histological and histometric observations. Morphometric study was performed on tissue from both the control and experimental animals to detect the diameter of seminiferous tubule (DST), height of germinal epithelium (HE) and thickness of interstitial tissue (TI). An Olympus microscope (Tokyo) with ocular micrometre lens X6 and an objective lens X40 was used for the measurements. For all measurements, the averages were calculated out of five readings (Thienpot et al., 1986).

Statistical analysis: Results were expressed as Mean \pm SD, analysed by using ANOVA followed by Tukey's t test. And the result was considered significant if $\mathrm{P}<0.05$.

\section{RESULTS}

Histology. Control groups: Seven-day postnatal testes showed the basal layer of the seminiferous epithelium being occupied by spermatogonia. They appear as rounded cells with large spherical nuclei (Fig. 1). A few primordial germ cells with processes are scattered randomly in the centre of the tubule. They are characterized by a large spherical nuclei and light cytoplasm. Sustentocytes (Sertoli cells) with elongated nuclei are found interspersed by spermatogonia (Fig. 1). On postnatal day 14, the seminiferous tubules showed a distinct basal lamina (Fig. 2). The outermost layer is formed of sustentocytes interspersed between

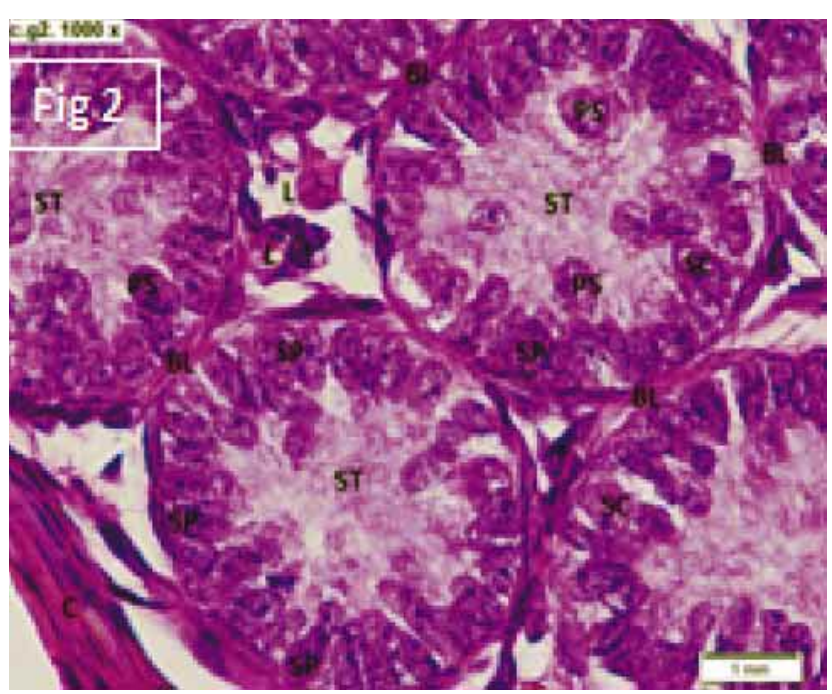

Fig. 2. A high power photomicrograph of seminiferous tubules of the testis of control rats (postnatal day 14) showing normal configuration of tubules basal lamina (BL), spermatogonia (SP), sustentocytes (SC) resting on the basal lamina and interstititial endocrine cells (Leydig cell) (L) in the interstitium (H\&E, X400). 
spermatogonia; spermatocytes appeared in the inner layer. The central part of the tubule was somewhat light with extending processes of primordial germ cells (Fig. 2). On day 21 of postnatal life, the outermost layers of the seminiferous tubules consisted of sustentocytes and spermatogonia. Primary and secondary spermatocytes were recognized in the inner layers of the tubules. Centre of tubules was filled with cytoplasmic processes of primordial germ cells (Fig. 3). Relative space occupied by interstitial tissue was reduced (Fig. 3). On postnatal days 28, 35 and 45 the testes of the control groups revealed normal structure and

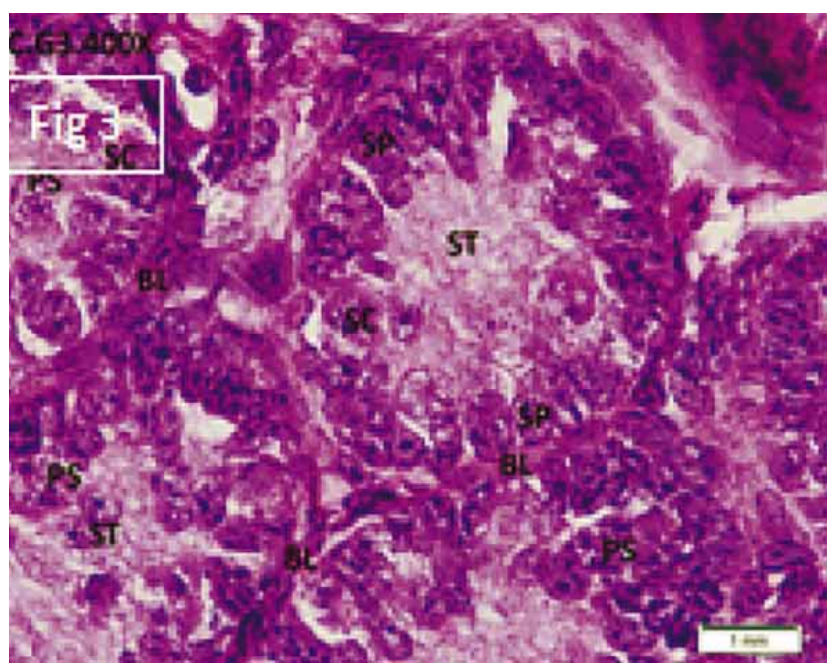

Fig. 3. A high power of seminiferous tubules of the testis of control rats (postnatal day 21) showing normal configuration of tubules basal lamina (BL), spermatogonia (SP), primary spermatocytes (PS), sustentocytes (SC) resting on the basal lamina and interstititial endocrine cells (Leydig cell) (L) in the interstitium (H\&E, X1000).

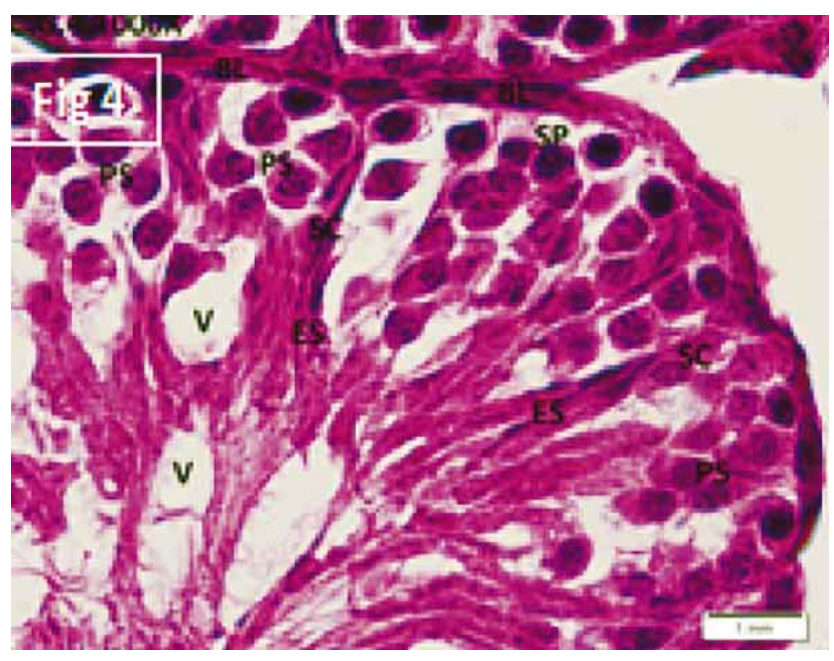

Fig. 4. A high power of seminiferous tubules of the testis of control rats (postnatal day 28) showing normal configuration of tubules basal lamina (BL), spermatogonia (SP), primary spermatocytes (PS), sustentocytes (SC) resting on the basal lamina and interstititial endocrine cells (Leydig cell) (L) in the interstitium (H\&E, X1000). all seminiferous tubules were intact (Fig. 4). The seminiferous epithelium is seen formed of Spermatogenic and sustentocytes (Fig. 4).

Hypoxic groups: In the hypoxic group 1 some of the seminiferous tubules showed detachment of the basal lamina. Spaces of different sizes have appeared within the epithelial layer with vacuoles in the centre. Pyknotic nuclei were noted in the spermatogonia and primordial germ cells. Such spaces were also seen within the intertubular tissue (Fig. 5). In the hypoxic group 2 there was also detachment of the basal lamina. Spaces within the epithelial wall, vacuoles in the center and pyknotic nuclei seen in the previous stage, were now less

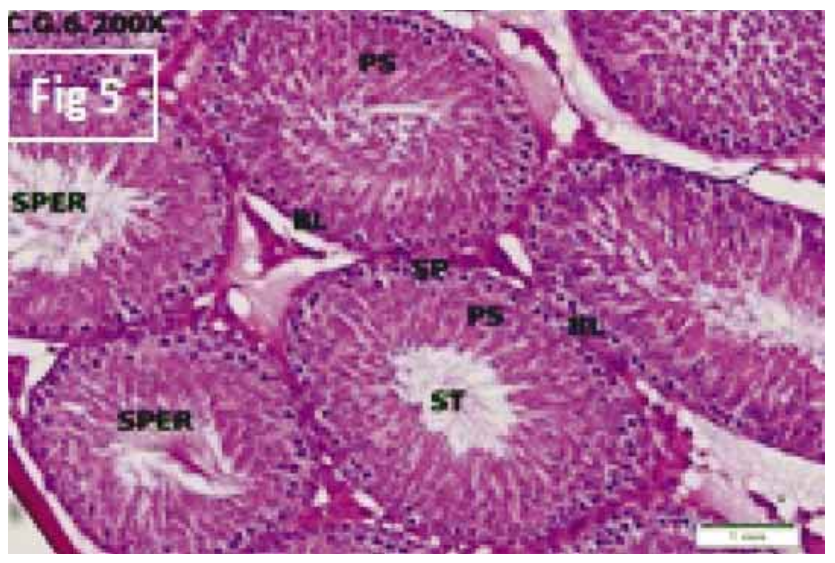

Fig. 5. A high power of seminiferous tubules of the testis of control rats (postnatal day 42) showing normal structure of tubules, basal lamina (BL), spermatogonia (SP), primary spermatocytes (PS), rounded and elongated spermatids (RS and ES respectively) spermatozoa in the lumen (SPER), sustentocytes (SC) resting on the basal lamina and interstititial endocrine cells (Leydig cell) (L) in the interstitium (H\&E, X400).

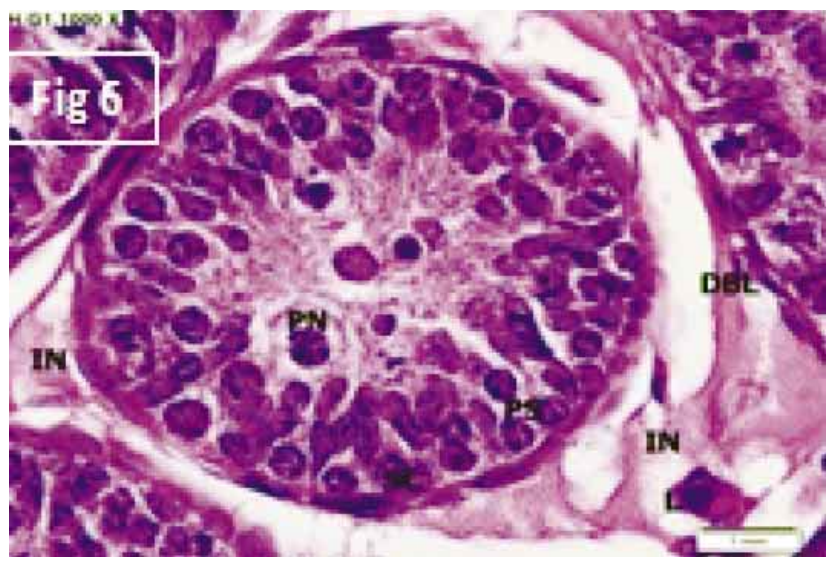

Fig. 6. Seminiferous tubules of the testis of high altitude rats (postnatal day 7) showing detached Basal lamina (DBL), spermatogonia resting on basal lamina and primary spermatocytes with pyknotic nuclei (PN) and interstititial endocrine cells (Leydig cell) (L) in the interstitial space. Wide interstitial spaces are observed (H\&E, X1000). 
remarkable, but spaces in the interstitial tissue became more numerous (Fig. 6). In the hypoxic group 3 the basal lamina was intact, but, pyknotic nuclei were observed in the spermatogonia and spermatocytes. The seminiferous tubules acquired a patent lumen for the first time. The intertubular tissue occupied a larger area than that of the control group of the same age (Fig. 7). Features of testes in hypoxic group 4 are essentially the same as those of group 3 except for fusion of some tubules and more vascularity (Fig. 8). In hypoxic group 5 a few rounded spermatids, were observed in the lumen, but spermatozoa were not yet developed. Pyknotic nuclei continued to be seen in the spermatogonia and spermatocytes (Fig. 9). In the hypoxic group 6 the seminiferous tubules appeared to have lost their usual configurations the basal laminae became folded together with an increased vascularity in the interstitium. Degeneration of the germ cells was observed in many tubules. The germinal epithelium showed more

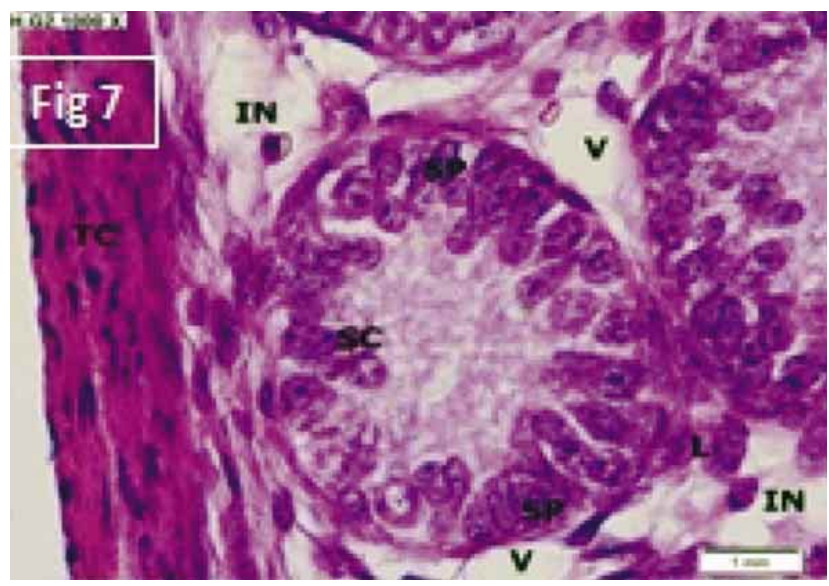

Fig. 7. Seminiferous tubules of the testis of high altitude rats (postnatal day 14) showing detached Basal laminae, (DBL), degenerated tubules (DT), fused tubules (FT) and wide interstitial space (H\&E, X400).

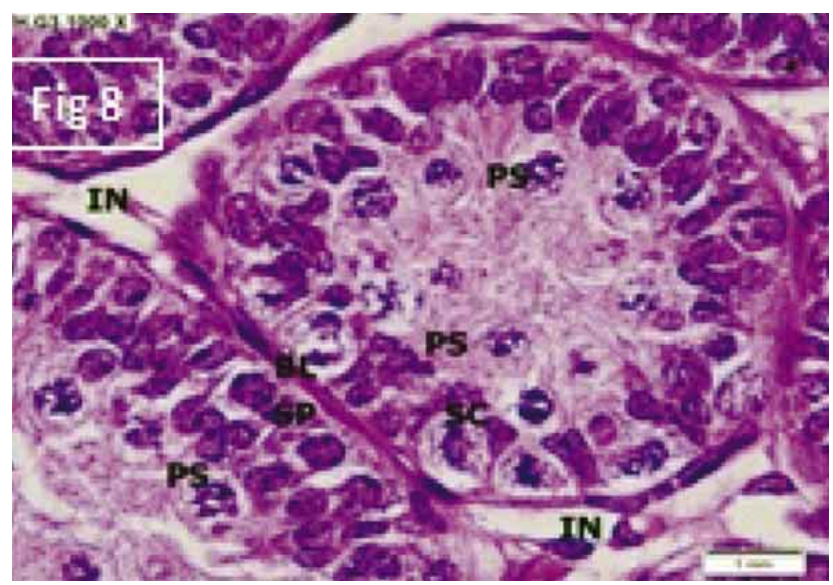

Fig. 8. Seminiferous tubules of the testis of high altitude rats (postnatal day 21) showing basal lamina (BL), spermatogonia (SP), primary spermatocytes (PS), sustentocytes (SC) and wide patent lumen (H\&E, X1000). vacuolation and the cells were disorderly arranged. Vacuolation was also observed in sustentocytes. There was a drop in the diameter of the seminiferous tubule and the thickness of the epithelial height; this was accompanied by concentration of the luminal content of spermatozoa (Fig. 10).

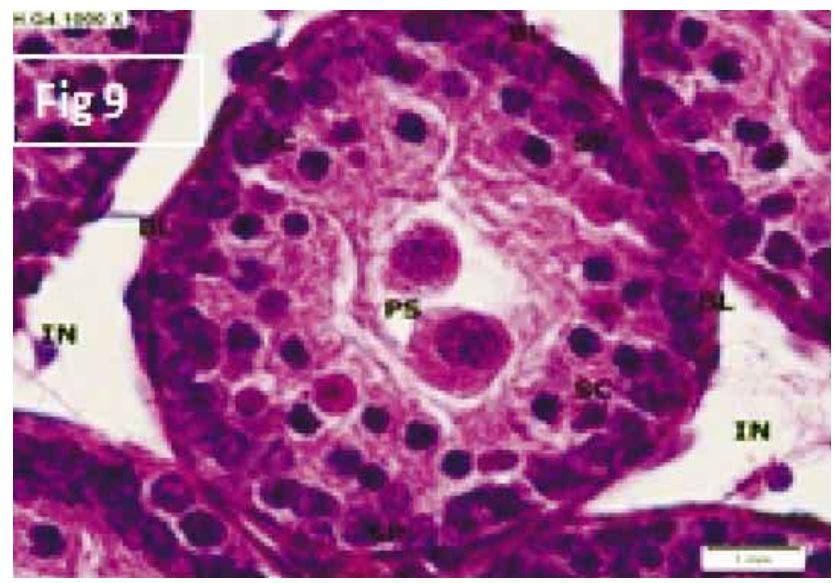

Fig. 9. Seminiferous tubules of the testis of high altitude rats (postnatal day 28) showing basal lamina (BL), spermatogonia (SP), primary spermatocytes (PS), sustentocytes (SC), large blood vessels are noticed in the interstitium (BV). Wide patent lumen $(\mathrm{H} \& \mathrm{E}$, X200).

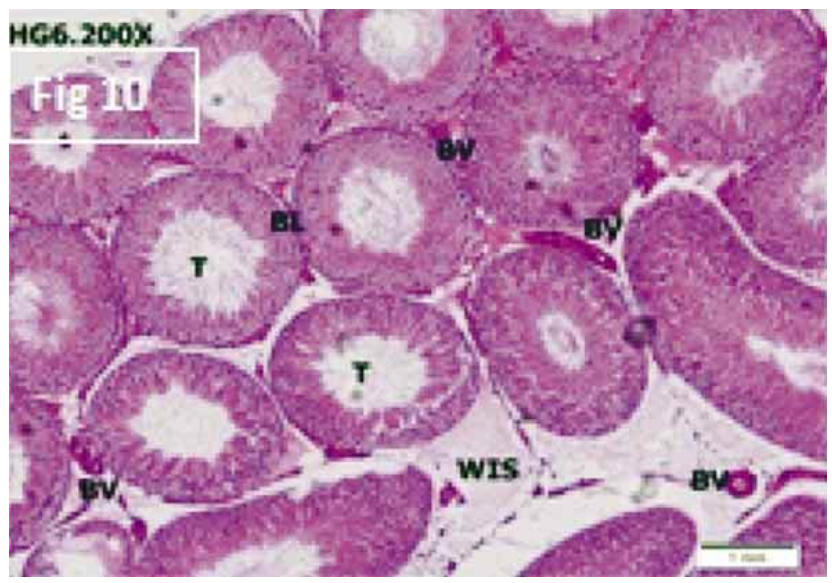

Fig. 10. Seminiferous tubules of the testis of high altitude rats (postnatal day 42) showing shrinkage of seminiferous tubules with concomitant increase in the interstitial space (WIS) and large blood vessels (BV) atrophic tubules (AT) (H\&E, X200).

Histometric analysis: Histometric analysis of sections of testes stained by Haematoxylene and Eosin (Table I) showed significant differences the diameter of the seminiferous tubule between all groups of rats exposed to HA environment at alltime intervals as compared to control LA group which showed reduction in the diameter of all hypoxic groups. Epithelial height was significantly reduced in all hypoxic groups as compared with the control groups. The ANOVA test revealed that the epithelial heights measured in hypoxic groups were significantly different from one another and from the con- 
Table I. Histometrical analysis of testis in all groups of rats.

\begin{tabular}{|c|c|c|c|}
\hline Group & Diameter of $\mathbf{S} . \mathbf{F}(\mu \mathrm{m})$ & Epithelial height $(\mu \mathrm{m})$ & Interstitial space $(\mu \mathrm{m})$ \\
\hline LA wk 1 & $71.9 \pm 39.1$ & $24.1 \pm 7.8$ & $63.6 \pm 15.9$ \\
\hline LA wk 2 & $119.3 \pm 37.5 \mathrm{a}$ & $38.7 \pm 13.2^{\mathrm{a}}$ & $110.1 \pm 30.1^{\mathrm{a}}$ \\
\hline LA wk 3 & $198.7 \pm 34.3 \mathrm{a}^{\mathrm{b}}$ & $47.8 \pm 6.7^{\mathrm{ab}}$ & $91.2 \pm 29.1 \mathrm{a}$ \\
\hline LA wk 4 & $209.8 \pm 38.1 \mathrm{a}^{\mathrm{b}}$ & $55.0 \pm 18.3 \mathrm{a}^{\mathrm{bc}}$ & $66.22 \pm 29.0^{\mathrm{c}}$ \\
\hline LA wk 5 & $274.6 \pm 71.7 \mathrm{a}^{\mathrm{bcd}}$ & $67.1 \pm 10.4 \mathrm{a}^{\mathrm{bcd}}$ & $86.8 \pm 49.2$ \\
\hline LA wk 6 & $290.8 \pm 57.2 \mathrm{a}^{\mathrm{bcd}}$ & $93.0 \pm 8.9^{\text {abcde }}$ & $100.7 \pm 46.1$ \\
\hline HA wk 1 & $69.66 \pm 11.1$ & $19.78 \pm 11.6$ & $35.2 \pm 1.1 *$ \\
\hline HA wk 2 & $71.38 \pm 21.6^{*}$ & $31.0 \pm 9.8$ & $33.5 \pm 10.7 *$ \\
\hline HA wk 3 & $95.5 \pm 19.1^{*}$ & $11.2 \pm 2.4 *_{\mathrm{a}}^{\mathrm{b}}$ & $29.2 \pm 11.1^{*}$ \\
\hline HA wk 4 & $88.58 \pm 16.8^{*}$ & $27.5 \pm 2.4^{* \mathrm{c}}$ & $24.4 \pm 11.7^{*}$ \\
\hline HA wk 5 & $135.0 \pm 26.1^{* \mathrm{abcd}}$ & $43.0 \pm 16.4 *_{\mathrm{a}}^{\mathrm{bcd}}$ & $55.7 \pm 6.4 * \mathrm{a} a c d$ \\
\hline HA wk 6 & $280.6 \pm 31.53 * \mathrm{a}$ bcde & $86.8 \pm 10.0 *$ abcde & $140.4 \pm 40.1^{* \text { abcde }}$ \\
\hline
\end{tabular}

Values were significantly different at $\mathrm{P}<0.05$. $\mathrm{a}=$ significantly different when compared to wk 1 group. $\mathrm{b}=$ significantly different when compared to wk 2 group. $\mathrm{c}=$ significantly different when compared to wk 3 group. $\mathrm{d}=$ significantly different when compared to wk 4 group. $\mathrm{e}=$ significantly different when compared to wk $5 . *$ Significantly different when compared to same time period corresponding group.

trol ones. On the other hand, gradual decreases in the interstitial space were seen in the testis of hypoxic groups of rats of weeks 1, 2, 3, 4 and 5 but an increase in the interstitial space was only observed in week 6 of hypoxic exposure as compared to the same period of time in the area of low altitude.

\section{DISCUSSION}

On day seven, postnatal testes in the control group showed a basal layer of the seminiferous epithelium being occupied almost entirely by the spermatogonia. They appeared as rounded cells with large spherical nuclei; sustentocytes with their elongate nuclei were interspersed between them. A few primordial germ cells with processes were scattered randomly in the center of the tubule. They were characterized by a large spherical nuclei and light cytoplasm. The interstitial tissue consisted of interstititial endocrine cells (Leydig cells), fibroblasts, collagenous fibers and blood vessels. In the hypoxic group of the same age some of the seminiferous tubules showed detachment from the basal lamina. Also, spaces of different sizes have appeared within the epithelial layer with vacuoles in the center. Pyknotic nuclei were noted in the spermatogonia and primordial germ cells. This is in accord with Liu \& Du (2002) that reported swelling in the interstitial space of rat testes as early as postnatal day 3 , and observed a few myoid cells with elongate nuclei in the peritubular tissue. On postnatal day 14 , the seminiferous tubules of the control group showed distinct basal laminae, unlike the hypoxic group of the same age in which the basal lamina was detached. Spaces within the epithelial wall, vacuoles in the center and pyknotic nuclei seen in the previous stage, were now less remarkable in the hypoxic group; this is in support of the observation of Shi \& Du (1998), who reported that the basal lamina was detached on postnatal day 14 of hypoxic rats, and less vacuoles were seen in the weeks after. By day 21, in addition to sustentocytes and spermatogonia, primary and secondary spermatocytes were recognized in both groups. Interstititial endocrine cells containing lipid droplets were frequently seen in interstitial space on (postnatal day 14 and 21) in hypoxic rats. These findings are inaccord with those of Liu \& Du, who reported the appearance of interstititial endocrine cells in the second week in hypoxic rats, and spermatids did not yet develop till the third week in the hypoxic rats. From postnatal day 28 onward, the testes of the control groups revealed normal structure of all seminiferous tubules. Clumps of heterochromatin were attached to the inner surface of the nuclear membrane. Whereas rounded spermatids were seen in the lumen only on day 35 of hypoxic group, no spermatozoa were recognized until day 45 of postnatal development. Pyknotic nuclei continued to be seen in the spermatogonia and spermatocytes. The interstitium became more vascular. This occurs as a compensatory change because hypoxia causes hypoxia-inducible factor-1a to stimulate vascular endothelial growth factor; this in turn promotes angiogenesis, augmenting blood flow and supplying more oxygen to the tissues (Semenza, 2000). On day Forty-five of postnatal hypoxic rats, the seminiferous tubules appeared to have lost their usual configuration as the basal laminae became folded together with degeneration of the germ cells in many tubules. More vacuolation was seen in the germinal epithelium, and the cells were disorderly arranged. Vacuolation was also observed in sustentocytes. There was a drop in the diameter of the seminiferous tubule and the thickness of the epithelial height; this was accompanied by concentration of the luminal content of spermatozoa. These findings are in support of earlier reports of Gosney and Biswas et al. (1985), who showed folding of basal laminae and vacuolations in sustentocytes. This study has shown that hypoxia increases the area of interstitial tissue within the testes. It is reasonable to accept 
the interpretation put forward by (Farias et al., 2005a) and Khmel nitskii \& Tararak (1991), suggesting that the spaces increase the oxygen diffusion area and subsequently impair oxygen arrival to the developing germ cells resulting in cell damage.

Histometry: In the current study, histometric analysis of testicular tissues showed significant differences in the diameter of the seminiferous tubules between all groups of rats exposed to HA environment at all-time intervals as compared to control LA group. There was a reduction in the diameter of seminiferous tubules of all hypoxic groups. The results of histometric analysis relating to epithelial height were essentially the same as those reported by (Farias et al., 2005b). In both studies there was a significant reduction in all-hypoxic groups as compared to the control groups, the ANOVA tests revealed that the epithelial heights measured in hypoxic groups were significantly different from one another as well as from the control groups.

ACKNOWLEDGEMENTS We wish to acknowledge the help of Dr. Muntaser Fadul and Dr. Assad Rizgellah.

MOHAMMED, H. M. \& TINGARI, M. D. Efecto de la hipoxia a gran altitud en el desarrollo postnatal en testículos de rata: Estudio histológico e histométrico. Int. J. Morphol., 34(2):610-615, 2016.

RESUMEN: El estudio se llevó a cabo en dos sitios de altitud diferentes en la región sur de Arabia Saudita: en Abha, a 2.800 metros sobre el nivel del mar, la zona de gran altitud (GA) y en Jazan, a 40 metros sobre el nivel del mar, la zona de baja altitud. Después de la exposición a GA, y hasta la tercera semana del desarrollo postnatal, se observaron espermatogonias y células germinales primordiales en algunos túbulos seminíferos, un desprendimiento de la lámina basal, espacios de diferentes tamaños dentro de la capa epitelial, con vacuolas en el centro y núcleos picnóticos. Se encontraron espermátidas redondeadas a nivel del lumen en el día 35 de la hipoxia, y no se observaron espermatozoides hasta el día 45 del desarrollo postnatal. En el día 45, los testículos de las ratas hipóxicas revelaron varios tipos de atrofia y degeneración en los túbulos seminíferos y el tejido intersticial; no hubo separación de las láminas basales de los túbulos y se registró una profunda disminución de la celularidad. Además, se observó una disminución significativa en la altura del epitelio de estos animales $(\mathrm{P}<0,05)$. El diámetro de los túbulos mostró una ligera disminución con el aumento concomitante en los espacios intersticiales en todas las ratas hipóxicas.

PALABRAS CLAVE: Gran altitud; Baja altitud; Hipoxia.

\section{REFERENCES}

Biswas, H. M.; Boral, M. C. \& Ghosh, A. K. Effect of hypobaric hypoxia on spermatogenesis, Leydig cells and delta 5-3 beta-hydroxysteroid dehydrogenase activity in toad. Indian J. Physiol. Pharmacol., 29(3):139-45, 1985.
Fahim, M. S.; Messiha, F. S. \& Girgis, S. M. Effect of acute and chronic simulated high altitude on male reproduction and testosterone level. Arch. Androl., 4(3):217-9, 1980.

Farías, J. G.; Bustos-Obregón, E. \& Reyes, J. G. Increase in testicular temperature and vascularization induced by hypobaric hypoxia in rats. J. Androl., 26(6):693-7, 2005b.

Farias, J. G.; Bustos-Obregón, E.; Orellana, R.; Bucarey, J. L.; Quiroz E. \& Reyes, J. G. Effects of chronic hypobaric hypoxia on testis histology and round spermatid oxidative metabolism. Andrologia, 37(1):47-52, 2005a.

Gosney, J. R. Effects of hypobaric hypoxia on the Leydig cell population of the testis of the rat. J. Endocrinol., 103(1):59-62, 1984.

Khmelnitskii, O. K. \& Tararak, T. Ia. Morphological characteristics of the pituitary-gonad system in high altitude hypoxia. Biull. Eksp. Biol. Med., 111(4):432-6, 1991.

Liu, J. X. \& Du, J. Z. Hypoxia alters testis development in neonatal rats. Neuro. Endocrinol. Lett., 23(3):231-7, 2002.

Nelson, M. L. \& Srebnik, H. H. Comparison of the reproductive performance of rats at high altitude $(3,800 \mathrm{~m})$ and at sea level. Int. J. Biometeorol., 14(2):187-93, 1970.

Saxena, D. K. Effect of hypoxia by intermittent altitude exposure on semen characteristics and testicular morphology of male rhesus monkeys. Int. J. Biometeorol., 38(3):137-40, 1995.

Semenza, G. L. HIF-1: mediator of physiological and pathophysiological responses to hypoxia. J. Appl. Physiol. (1985), 88(4):1474-80, 2000.

Shi, X. J. \& Du, J. Z. Effects of hypoxia on the gonads in male rats. Chin. J. Pathophysiol., 43:162-5, 1998.

Thienpont, D.; Rochelle, F. \& Vanparijs, O. F. J. Diagnosing Helminthiasis by Coprological Examination. 2nd ed. Beerse, Janssen Research Foundation, 1986. pp.26-7.

Timiras, P. S.; Krum, A. A. \& Pace, N. Body and organ weights of rats during acclimatization to an altitude of 12,470 feet. Am. J. Physiol., 191(3):598-604, 1957.

Vats, P.; Singh, V. K.; Singh, S. N. \& Singh, S. B. Glutathione metabolism under high-altitude stress and effect of antioxidant supplementation. Aviat. Space Environ. Med., 79(12):1106-11, 2008.

Voss, P. \& Siems, W. Clinical oxidation parameters of aging. Free Radic. Res., 40(12):1339-49, 2006.

Correspondence to:

Dr. Heitham Mutwakil Mohammed

Department of Anatomy

Faculty of Medicine

Jazan University, P.O.

Box 114, Jazan

SAUDI ARABIA

Email: mutwakilheitham@gmail.com

Received: $24-12-2015$

Accepted: 23-03-2016 